\title{
Agama Kristen dan Hoax: Peran Agama Kristen Dalam Menekan Hoax
}

\author{
Donny Paskah Martianus Siburian \\ Magister Sosiologi, Universitas Sumatera Utara. \\ donipasca@gmail.com
}

\section{D01: https://doi.org/10.34307/b.v4i2.257}

\begin{abstract}
In the 4.0 era information has been transforming much faster and influencing daily interactions. Based on social recent phenomenon people were not given the interest to utilize these opportunities to look for the truth instead of prioritizing emotions, preferences to justify. This social atmosphere absolutely reduces the essential meaning of the 'truth' itself. The 'truth' and 'untruth' can not be seen. The capability to analyze by the clear mind of intellect as one of the values of being a religious human has been paralyzed. The truth is claimed by like or dislike to something. How religion especially Christianity has its crucial functions as a social institution to reduce the hoax spreading behavior in its congregation will be provided in this paper. This study took palace in the HKBP Church in Bagansiapiapi, Rokan Hilir, Riau, Indonesia using the qualitative approach by taking the data from observation and interviews. The result shows found that religion by its dogma and religious leader comprehensively reduce the hoax spreading behavior in the congregation.
\end{abstract}

Keywords: Christianity, Hoax, HKBP, post truth

Abstrak: Realitas Kemajuan Informasi 4.0 telah memengaruhi kehidupan. Berdasarkan fenomena terkini memperlihatkan bahwa orang-orang tidak lagi mau memberikan perhatian pada kebenaran yang hakiki dari sebuah informasi yang ia terima. Melainkan cenderung mengklaim kebenaran tersebut seturut dengan preferensi subjektif. Atmosfer kehidupan sosial seperti ini mereduksi perbedaan antara suka-tidak suka dan benarsalah menjadi demikian tipis. Alih-alih menjalani proses nalar yang panjang dan melelahkan, masyarakat cenderung tergesa-gesa mengklaim sesuatu yang disukainya sebagai kebenaran, sebaliknya tergesa-gesa menganggap salah atau sesat sesuatu yang dibenci/tidak disukai. Penelitian ini mencoba mengeksplorasi bagaimana agama sebagai pranata, khususnya agama Kristen memainkan peran yang krusial pada fenomena hoax. Penelitian ini dilaksanakan di Jemaat Gereja HKBP Bagansiapiapi ressort Bagansiapiapi, kabupaten Rokan Hilir, provinsi Riau-Indonesia menggunakan metodologi penelitian kualitatif dengan teknik wawancara dan observasi. Temuan memperlihatkan bahwa agama Kristen secara sistematis dan praksis menjalankan perannya sebagai pranata sosial melalui lembaga gereja. Peran tersebut berakar dari doktrin yang menekan prilaku penyebaran hoax. Penelitian juga memperlihatkan pemuka agama andil dalam menekan perilaku penyebar hoax bagi jemaat

Kata Kunci: Agama Kristen, Hoax, HKBP, Pasca kebenaran.

\begin{tabular}{llll}
\hline Article History : & Received: 17-04-2021 & Revised: 01-12-2021 & Accepted: 03-12-2021
\end{tabular}




\section{Pendahuluan}

Antara bulan Maret sampai dengan April 2016 lalu beredar sebuah desas-desus sesosok bidadari jatuh di sekitar perairan Pulau Banggai, Sulawesi yang ditemukan seorang nelayan. Berita ini menyebar dengan cepat dan mengambil perhatian banyak orang kemudian diteruskan oleh berbagai media online termasuk ke luar negeri. Sekitar akhir April Kapolres Banggai mengumumkan bahwa sosok bidadari dalam berita itu adalah boneka intim. ${ }^{1}$

Pada pertengahan tahun 2018 lalu berita tentang anak bertelur juga sempat menjadi perbincangan popular pada banyak kalangan. Anak ini disinyalir menghasilkan telur dalam tubuhnya sehingga mencuri atensi publik. Masyarakat menganggap bocah ini sakti. Namun setelah pemeriksaan medis ternyata hal itu didiagnosa sebagai sebuah kasus pengapuran. Alih- alih menjadi berita yang demikian sensasional kita seharusnya prihatin atas apa yang terjadi pada anak tersebut. ${ }^{2}$

Contoh-contoh tersebut di atas adalah fenomena yang memberikan gambaran gejala menarik sejak media sosial berkembang. Orang-orang semakin mudah mengedarkan segala macam berita, mulai dari berita serius sampai desas-desus politik, kabar burung, takhyul, perang ideologi, cerita gaib, rasisme dan sebagainya. Masalahnya dewasa ini memeriksa suatu kabar acapkali menuntut sebuah jerih payah yang lebih daripada sekadar meneruskan berita tersebut. Kemudahan dalam meneruskan informasi dewasa ini membuat kebanyakan orang cenderung menjadi penerus kabar burung yang belum tentu benar. Sekurang-kurangnya hal demikian dianggap memberikan kesan up to date. Ditengah tengah kemudahan informasi dan komunikasi yang kian memperlihatkan puncak geliatnya, berita beredar dengan sangat cepat melampaui batas-batas ruang yang pada masa lampau menjadi masalah utama informasi.

Arus komunikasi yang seharusnya mampu memberikan akses pengetahuan akan keadaan terkini, juga digunakan untuk menyebarkan sesuatu yang tidak benar. Yang justru mengacaukan keadaan. Dalam kemudahan itu setiap orang dapat menerbitkan, dan meneruskan opini seturut pada kaidah dan pemahamannya sendiri. Bukan dengan fakta realitas atau kebenaran yang sesungguhnya. Oleh sebab itu acuannya bukan terletak pada seberapa jauh kesahihan tersebut dapat teruji, melainkan pada sensasionalitas berita. Inilah yang menggejala pada masa kini, berita-berita muncul dan diterima begitu saja secara emosional. ${ }^{3}$ Adapaun penelitian ini bertujuan menyajikan bagaimana Agama

1 “Bidadari Yang Jatuh Dari Langit Sulawesi Ternyata Boneka Seks," diakses 02 Maret 2021, https://www.suara.com/news/2016/05/02/105540/bidadari-yang-jatuh-di-langit-di-sulawesi-ternyataboneka-seks.

2 “Teka-Teki Bocah Bertelur Itu Akhirnya Terbongkar, Polisi Pun Menutup Kasusnya," diakses 2 Maret 2021, https://www.tribunnews.com/regional/2018/03/05/teta-teki-bocah-bertelur-itu-akhirnyaterbongkar-polisi-pun-menutup-kasusnya.

${ }^{3}$ Silmi Novita Nurman, "Penguatan Islam Moderat Di Era Post Truth," Jurnal Al Aqidah 11, no. 2 (2019): 179-188. 
Kristen sebagai sebuah pranta sosial berperan menekan hoax dalam perilaku bermedia sosial jemaat, serta menganalisisnya dari perspektif sosiologis.

\section{Metode Penelitian}

Metodologi penelitian yang digunakan adalah metodologi penelitian kualitatif dengan strategi pengumpulan data observasi dan wawancara. Sumber-sumber data menggunakan literatur pustaka, dan informan. Informan adalah orang-orang yang akitf dalam kegiatan keagamaan Kristen di gereja Huria Kristen Batak Protestan (HKBP) Bagansiapiapi, Rokan Hilir, Riau, Indonesia. Penulis mengombinasikan pendekatan sosiologis untuk memahami pemaknaan informan terhadap fenomena post truth. Observasi juga dilakukan secara terselubung untuk mendapatkan hasil yang akurat pada penelitian. Wawancara dalam penelitian ini dilakukan secara tidak terstruktur. Menurut Sugiyono menyebutkan bahwa penggunaan wawancara tidak terstruktur. Maksudnya adalah peneliti tidak mempersiapkan pedoman acuan baku dalam wawancara terhadap informan, melainkan pertanyaan muncul dan berkembang sesuai keadaan. ${ }^{4}$

\section{Hasil dan Pembahasan}

\section{Hoax Diperanakkan Post Truth}

Kamus Umum Bahasa Indonesia kebenaran didefinisikan sebagai keadaan yang sesungguhnya: sesuatu yang sungguh dan betul demikian: kejujuran, ketulusan dan integritas. Dengan demikian bila diuraikan kebenaran adalah sebagai berikut: Pertama, bermakna yang sesungguhnya dari suatu pernyataan yang sesuai dengan pengetahuan manusia. Kedua, suatu pernyataan komprehensif dari pernyataan-pernyataan yang berhubungan dan 'logis' dengan pernyataan-pernyataan lainnya yang sudah lebih dahulu diketahui, diterima, dan diakui sebagai benar dan fakta.

Selanjutnya Kamus Besar Bahasa Indonesia (KBBI) menjelaskan bahwa fakta ialah keadaan atau peristiwa kenyataan. Sebagai sesuatu yang benar ada atau terjadi, dapat disebutkan berisi fakta merupakan sebuah informasi berdasarkan kenyataan, peristiwa, dan suasana yang benar terjadi seobjektif mungkin.

Merujuk makna Post truth Manner (1996) mendefinisikan post truth dengan sebagai simpulan sebuah peristiwa di mana peristiwa itu telah terjadi. Secara etimologi post truth dapat diartikan 'melampaui' atau 'pasca-kebenaran'. ${ }^{5}$ Shayuda menyebutkan bahwa Post truth adalah kondisi di mana fakta tidak terlalu berpengaruh dalam membentuk opini publik. ${ }^{6}$ Dengan demikian post truth adalah keadaan di mana sensasionalitas serta emosi lebih dipentingkan dari pada fakta yang berhubungan pada sebuah berita. Bentuk langsung dari post truth adalah fenomena hoax yang dapat kita

\footnotetext{
${ }^{4}$ Sugiyono, Metode Penelitian Kuantitatif Kualitatif (Bandung: Alfabeta, 2019), 306-307.

${ }^{5}$ Ulya, "Post-Truth, Hoax Dan Religiusitas Di Media Sosial"," Fikrah 6, no. 2 (2018): 284.

${ }^{6}$ Kharisma Dhimas Syuhada, "Etika Media Di Era Post-Truth”," Jurnal Komunikasi Indonesia 5, no. 1 (2017): 76.
} 
jumpai di media-media sosial. Hoax adalah sebuah berita bohong yang dikonstruksi dengan tujuan untuk mendiskriminasi, popularitas, propaganda, menyulut emosi dan sebagainya. Hoax muncul dan menjadi populer akibat publik lebih mementingkan hal-hal yang menyentuh perasaan dari pada fakta dan untuk itu tidak begitu tertarik menggunakan nalarnya. Suatu kondisi di mana fakta tidak lagi dapat menggerakkan kepercayaan publik, emosi dan kebanggaan tertentu (seperti agama, kepercayaan, kebangsaan, ras, etnis dan kepentingan politik) mengambil peran yang seharusnya dari fungsi sebuah nalar untuk menelisik kebenaran. Sebagaimana telah disinggung bahwa fenomena hoax muncul sebagai modifikasi dari dampak laten post truth dengan preferensi emosi dalam menimbang sebuah kebenaran informasi, dewasa ini berita-berita hoax semakin merajalela sebab kecenderungam masyarakat yang meletakkan nilai benar tergantung dari apakah suatu informasi sesuai dengan afiliasi seorang individu. Misalnya dalam afiliasi politik pada kontestasi presiden Republik Indonesia tahun 2019 yang lalu isu Jokowi anak PKI sengaja dibuat untuk mengganggu elektabilitas politik Jokowi dan partainya. ${ }^{7}$ Bagi mereka yang kontra Jokowi maka hal ini akan dianggap sebuah kebenaran dan 'diteruskan' pada laman sosial media. Selain kasus tersebut, untuk kepentingan populeritas misalnya ditemukan beberapa tahun yang lalu sesorang yang mengaku sebagai petinggi kekaisaran Sunda (Sunda Empire) yang akan bangkit menguasai dunia. ${ }^{8}$ Demikianlah berita hoax dibuat untuk kepentingan tertentu dan maksud yang berbeda beda.

Lajunya akses informasi dan budaya 'salin-teruskan' turut memiliki andil dalam menyuburkan post truth. Pembatas antara kebenaran atau kebohongan semakin tipis. Masyarakat lebih mencari pembenaran dibandingkan selera untuk menguji sebuah kebenaran. Meskipun post truth berkembang cepat, akibat dukungan internet dan media sosial, namun beberapa orang menganggap nalar post truth ini dilahirkan oleh filsafat post-modernisme. Lee McIntyre sebagaimana dikutip oleh Widodo ${ }^{9}$ menyebutkan kebangkitan pembiakan massive post truth yang menolak 'objektivitas dan kebenaran objektif merupakan anak dari perkembangan filsafat post-modernisme. Keberanian berpikir bahwa kebenaran tidak terletak pada sebuah objek, melainkan subjek. Lantas pertanyaannya apakah 'fakta objektif' itu? Dapatkah sesuatu menjadi 'fakta objektif' di luar kehendak subjek yang mengenalinya? Adakah fakta-objektif yang berdiri di luar karena dibuat oleh manusia?

7 "Kementerian Komunikasi Dan Informatika," diakses November 5, 2021, https://www.kominfo.go.id/content/detail/29641/hoaks-bambang-trihatmodjo-buktikan-jokowiberasal-dari-keluarga-pki/0/laporan_isu_hoaks.

8 "Sejarah Kerajaan Sunda Empire Di Bandung Jawa Barat | Tagar," diakses 05 November, 2021, https://www.tagar.id/sejarah-kerajaan-sunda-empire-di-bandung-jawa-barat.

${ }^{9}$ Widodo Dwi Putro and Tristam Pascal Moeliono, “Apakah Ada Kebenaran Hukum Di Era PostTrurth," in Menemukan Kebenaran Hukum Dalam Era Post-Truth, ed. Tristan Pascal Moelino (Mataram: Sanabil, 2020), 4. 
Michel Foucault (1926-1984) seorang pemikir postmodernisme Prancis sebagaimana dikutip oleh Ahmad Stabik menganggap kebenaran adalah sistem prosedural untuk menghasilkan, mengatur, mendistribusikan, mensirkulasikan dan menjalankan pernyataan-pernyataan. ${ }^{10}$ Oleh karena itu kebenaran selalu berhubungan dengan bermacam-macam bentuk diskursus. Suatu tindakan bisa saja benar bagi suatu diskursus namun akan menjadi keliru (salah) dalam sebuah diskursus lain Contohnya, tindakan memukul akan dinilai sebagai kejahatan bagi diskursus hukum pidana juga agama tetapi bagi diskursus lain, tinju misalnya, memukul selagi mematuhi aturan bertinju akan dianggap prestasi. Pada kasus ini agama dan sains adalah dua diskursus yang berbeda yang menghasilkan pendapat yang berbeda tentang sebuah gejala yang sama.

Dengan begitu penolakan kebenaran pada objek dalam pandangan postmodernisme tidak bisa dianggap sebagai kejatuhannya dalam post truth yang dekaden. Postmodernisme dalam pandangan Foucault hendak memperlihatkan sebuah kebenaran dibentuk dengan mempertimbangkan kepentingan ilmuwan secara subjektif yang dipengaruhi oleh semangat atau keadaan zamannya. Tapi tidak berarti bahwa fakta kebenaran yang objektif terdapat di luar subjek yang mengenalinya. Apabila objektivitas dan kebenaran objektif itu ada bukan berarti ada perbedaan dan perubahan kebenaran tentang suatu hal dalam ruang dan waktu yang berbeda. Artinya fakta sebuah kebenaran dapat terukur dan dialami secara menyeluruh tidak terbatas pada suatu subjek kaum secara khusus. Oleh sebab itu seorang ilmuwan postmodern akan tetap secara kritis mematuhi prosedur-prosedur ilmiah saat menyatakan pendapatnya. Karena itu seorang postmodernis juga akan menolak post truth. Telah lama dalam sejarah manusia ihwal 'kebenaran' menjadi sebuah pertanyaan tanpa ambang batas. Bahkan pertanyaan ini telah menjadi pertanyaan filsuf-filsuf klasik sejak zaman kuno. Perdebatan mendasar itu telah menjadi diskursus seputar asal-usul dan kategori kebenaran. Manusia yang hidup idealnya memiliki kehendak untuk mengetahui kebenaran tersebut dengan demikian terfokus pada sumber pengetahuan, proses, dan metode untuk memperoleh pengetauan sebagai cara untuk membuktikan kebenaran. ${ }^{11}$

\section{Peran Agama Kristen Dalam Menekan Hoax Doktrin Agama}

Berger menyebutkan bahwa tidak ada masyarakat/manusia yang mengalami stagnansi. Perubahan terjadi sebagai bagian dari hidup akibat terus berpikir dan berkembang oleh proses sosialiasi dari setiap interaksi individu. Berger memberikan definisi yang aksiomatis bahwa masyarakat mengalami perkembangan secara absolut, terus-meneruas, dinamis, dan akan selalu mengalami perubahan dalam berbagai bidang

\footnotetext{
${ }^{10}$ Ahmad Stabik, "Teori Kebenaran Perspektif Filsafat Ilmu," Jurnal Fikrah 2, no. 1 (2014): 254.

${ }^{11}$ Ibid, 253.
} 
kehidupannya. Hal itu terjadi demikian karena manusia selalu mengalami internalisasi dari pengalaman empiris. Maka realitas sosial juga akan mengalami perkembangan dan proses. ${ }^{12}$ Letak akal, nalar, dan pikiran menjadikan nilai-nilai yang dikoleksi dalam kehidupan melalui berbagai sosialisasi menjadikan manusia beranjak dari sebuah kondisi ke kondisi berikutnya (disebut: perkembangan). Manusia disebut istimewa dari hewan karena ia mampu menginternalisasi nilai dan pengetahuan dari luar dirinya, memprosesnya di pikiran, dan mendayagunakan itu sebagai pengetahuan yang berguna bagi kemaslahatan sosial. Artinya manusia mengalami perkembangan karena kemampuan berpikir dan mengelola makna yang diperolehnya secara empiris dan kritis. Informasi yang tidak bertentangan juga dicatat dalam Kitab Kejadian bahwa manusia diciptakan segambar dengan Allah (Imago Dei) yang diidentifikasi oleh Samho bahwa itu berarti menekankan manusia yang memiliki akal dan budi. ${ }^{13}$ Dengan demikian sebagai manusia kita dituntut untuk aktif berpikir kritis dan mempertanggung jawabkan hasilnya. Kritis berarti berfokus untuk memutuskan apa yang mesti dipercayai atau dilakukan. Dengan kata lain, berpikir kritis merupakan bagian dari penalaran yang melibatkan proses mental untuk menganalisis atau mengevaluasi informasi demi memahami informasi secara mendalam.

Di Indonesia, fenomena post truth berhubungan erat dengan hoax dan dapat di amati dengan sangat jelas pada tahun 2017 lalu saat pemilihan Gubernur DKI Jakarta dan pemilihan Presiden pada tahun 2019 lalu. Pada pemilihan Gubernur DKI Jakarta isu ras dan agama mencuat kepermukaan sehingga tidak sedikit orang yang mengedepankan preferensi emosi dan agama dalam melihat sebuah informasi. Dalam menanggapi isu-isu tersebut yang muncul segera setelah kontestasi pemilihan umum banyak kalangan mulai memberikan penilaian berdasarkan preferensi perasaan sehingga jatuh pada subjektivitas yang emosional, perasaan suka-tidak suka untuk menilai kebenaran (berita) dari masing masing calon pasangan. Misalnya sunatullah dikutip untuk menjelaskan bagaimana seharusnya air yang menjadi penyebab utama masalah banjir di ibu kota Jakarta seharusnya tidak dialirkan ke laut namun ke dalam tanah yang jelas-jelas dipergunakan untuk memojokkan pasangan calon pesaingnya yang adalah non-muslim oleh salah satu pasangan calon pada waktu itu. ${ }^{14}$ Agama dalam hal ini sunatullah menjadi alat untuk menyulut emosi dan preferensi publik padahal kebenarannya belum tentu demikian maksuda dan konteks dari sunatullah yang dimaksudkan harus diidentifikasi secara komprehensif sehingga tidak menjadi hoax. Akan tetapi publik malah tersulut dan menyalahkan pasangan incumbent pada waktu itu, bukan hanya di kawasan ibu kota

\footnotetext{
${ }^{12}$ Muria Herlina, Sosiologi Kesehatan (Surabaya: Muara Karya, 2017), 24.

${ }^{13}$ Bartolomeus Samho, Agama Dan Kesadaran Kontemporer (Yogyakarta: Kanisius, 2019), 119.

14 “Anies: Jika Air Hujan Masuk Ke Tanah, Insyaallah Tak Ada Banjir," diakses 5 November 2021, https://news.detik.com/berita/d-4309249/anies-jika-air-hujan-masuk-ke-tanah-insyaallah-tak-ada-
} banjir. 
Jakarta tetapi seluruh masyarakat yang antusias mengikuti jalannya kontestasi politik tersebut melalui berbagai media masa terhubung online di seluruh Indonesia. ${ }^{15}$

Bukan hanya bagi agama non Kristen, isu agama juga laris manis untuk dibuat menjadi dasar berita hoax bagi orang-orang Kristen. Bagi kaum fundamentalis Kristen, acap kali tatkala bersinggungan dengan iman kita mengabaikan akal budi. Harus diakui bahwa tidak seluruh realitas yang dapat kita temui sekarang ini bersinggungan langsung dengan apa yang diilhamkan oleh Allah pada teks-teks suci agamawi orang-orang Kristen (Alkitab). Misalnya hoax bahwa COVID 19 merupakan nubuatan akhir zaman sebagaimana dalam Kitab Wahyu (Pasal 16), ${ }^{16}$ demikian pula bahwa LGBT merupakan fenomena yang menjadi penanda antikristus. Atau barangkali narasi-narasi yang mengejawantahkan bahwa Allah menjaga orang-orang percaya, virus COVID 19 tidak dapat menginfeksi orang-orang percaya sehingga berdoa lebih penting dari pada vaksin. ${ }^{17}$ Hal ini terjadi karena memahami agama pada konsep yang dangkal bahwa teks-teks agamawi dimaknai secara harfiah sehingga tidak merasa tertuntut untuk menggunakan penelitian hermenutik yang komprehensif dalam menjelaskan makna dari teks-teks agamawi. Hal ini yang menyebabkan tidak sedikit orang beragama dewasa ini menerima informasi tersebut lantas memercayainya begitu saja. Singkatnya otoritas agamawi pada kasus di atas yang seharusnya dapat menekan tindakan penyebaran hoax justru juga dapat didisfungsi oleh oknum-oknum tertentu dengan menjadikan hoax dengan tema agamis yang apik sehingga lebih licin untuk masuk dan memengaruhi penganut agama tersebut. Tentu dalam kondisi fundamentalisme seperti ini hal-hal apapun yang bersinggungan dengan iman sifatnya dianggap mutlak dan dianggap benar. Dalam penanggulangan penyebaran hoax fundamentalisme terhadap agama atau apapun sesungguhnya harus disingkirkan untuk menciptakan daya kritis.

Agama memang berperan sangat strategis di samping lembaga-lembaga lain dalam mensosialisasikan sikap anti hoax pada jemaatnya (masyarakat). Hal ini sangat berkaitan erat dengan sikap dan atmosfer keberagamaan di Indonesia yang masih sangat mengikat serta mendominasi masyarakat sebagai acuan dalam perilaku kehidupan sehari-hari. Agama sebagai sebuah sistem pengetahuan juga keyakinan, menyediakan informasi dalam teks-teks suci, kecenderungan pemeluk agama menganggap klaim kebenaran secara sepihak. Boleh jadi dalam keadaan demikian menjadikan agama sebagai sarana

15 "Anies-Sandi Menang, Warga Pekanbaru Ini Cukur Habis Rambutnya - Cakaplah - Berpikir Berbuat Bercakap," diakses 05 November 2021, https://www.cakaplah.com/berita/baca/ 4066/2017/04/20/aniessandi-menang-warga-pekanbaru-ini-cukur-habis-rambutnya.

16 "Kolom: Pandemi Corona Pertanda Akhir Zaman? | SOSBUD: Laporan Seputar Seni, Gaya Hidup Dan Sosial | DW | 12.03.2020," diakses 02 Maret 2021, https://www.dw.com/id/kolom-pandemi-coronapertanda-akhir-zaman/a-52739489.

17 “Klaim Bisa Sembuhkan Penderita Virus Corona, Pendeta Ini Meninggal Karena Penyakit Yang Sama Halaman All - Kompas.Com," diakses 20 Maret 2021, https://www.kompas.com/global/read/ 2020/05/20/134441970/klaim-bisa-sembuhkan-penderita-virus-corona-pendeta-ini-meninggal-karena? page $=$ all. 
pendorong tindakan kekerasan, propaganda, hoax dsb. Kepentingan agama dalam hal otoritas dan validasi menjadi tumpang tindih dengan nilai dalam agama itu sendiri.

Menurut teori struktural fungsional bahwa struktur sosial dan sebuah pranata sosial berada atas bagian dari elemen-elemen yang lain yang saling berhubungan dan membangun menuju suatu keseimbangan (equilibrium). Teori ini melihat bahwa sistem sosial identik dengan organisme biologis. Disebut fungsional struktural karena pandangan ini melihat bahwa sebuah struktur dalam system sosial masyarakat adalah fungsional terhadap struktur sosial yang lainnya.

Lawrence Kohlberg, profesor di bidang pendidikan juga psikologi sosial dari Universitas Harvard memberikan keterangan dalam penelitian yang digarapnya dengan menyebutkan bahwa proses perkembangan moral bagi manusia sesungguhnya tidak menemui akhirnya hingga individu tersebut berakhir. ${ }^{18}$ Berbagai jenis teori berhubungan dengan perkembangan moral dan perilaku tersebut menggambarkan bahwa tubuh manusia adalah kompleks sebagai mahluk biologis, energi dalam diri manusia dalam sistem yang kompleks itu memelihara diri dalam relasinya dengan dunia luar. Ini yang disebutkan sebagai tehnik manusia untuk mempertahankan dirinya, jenisnya dan kaumnya menurut hukum evolusi. ${ }^{19}$ Selanjutnya pada dekade akhir abad ke 19 teori lain muncul dengan pengaruh sosiologi dan ilmu antropologi yang popular pada masa itu. Bahwa manusia adalah cenderung makhluk sosial dari pada makhluk biologis, manusia dibentuk sebagai hasil dari masyarakat di mana dia hidup dalam lingkungannya. Jelas bahwa perkembangan moral juga perilaku manusia dalam masyarakat bukanlah dipengaruhi oleh proses-proses yang kodrati namun melalui dan berproses dalam sebuah pembelajaran yang panjang dan kompleks (learning process), yang dalam istilah teknis bidang sosiologi disebut 'proses sosiologis'. Perkembangan moral dan juga perilaku menurut Koentjaraningrat tidak terlepas dari pembentukan oleh lingkungan selama masa hidup individu. Hal ini menurutnya serba berpranata, serba bersistem atau mengandung norma-norma sosial yang terorganisir dan mengatur setiap perilaku warga masyarakat

Agama sebagai pranata sosial memiliki peran yang sangat penting memengaruhi perilaku, dan cara berpikir para penganutnya dalam kehidupan sehari-hari. Memang teori tentang apa agama dan apa fungsi agama juga banyak dan bermacam-macam. ${ }^{20}$ Jelas bahwa nilai-nilai agama yang disakralkan adalah orientasi dalam membangun sistem hukum dan konsep-konsep sosial. Peran penting agama atau nilai-nilai agama dalam

${ }^{18}$ L. Kohlberg, "Cognitive-Development Theory and the Practice of Collective Moral Education," in Group Care: The Educational Path of Youth Aliyah, ed. M. Collins and M. Gottesman (New York: Gordon and Breach, 1971); Ronald Duska and Mariellen Whelan, "Cognitive-Developmental Approach to Moral Education," in The Humanist, November-D., 1972.

${ }^{19}$ Sumadi Suryabrata, Psikologi Kepribadian (Jakarta: Raja Grafindo Persada, 2003), 15-50.

${ }^{20}$ Max Muller, Introduction to Science of Religion (London: Longman Green and Co, 1982). 
bahasan ini berfokus pada doktrin agama yang berdampak pada prilaku yang menekan kecenderungan penyebaran hoax

Hasil penelitian ini menunjukkan adanya pengaruh agama sebagai pembentuk moral perilaku dalam mengembangkan sikap selektif dan kritis menyeleksi informasi. Selain itu ditemukan bahwa jemaat gereja merasa tertuntut untuk memberikan informasi yang sahih dalam bermedia sosial. Sehingga selektif dalam membagikan postinganpostingan di media sosial. Alih-alih tertarik membagikan isu-isu kontemporer yang masih belum dikatahui kebenarannya pengamatan pada masing-masing akun media sosial mereka memperlihatkan kecenderungan membagikan kiriman-kiriman religius (naskahnaskah alkitab), kegemaran dan hobi dari pada membagikan isu-isu kontemporer berkenaan dengan politik, agama dan ideologi tertentu yang sarat akan penyebaran hoax.

Hal ini disebabkan upaya untuk menjadi selektif dalam meneruskan informasi sehingga tindakan-tindakan kebencian yang dapat memberikan dampak buruk dan dosa akan terhindar. Dari pandangan ini kita dapat melihat bahwa doktrin gereja sebagai sebuah lembaga sosial bersifat mengikat. Mengikuti alur berpikir Kristiani hoax berarti bersaksi dusta, dan hal itu melanggar Hukum Taurat ke 9 (Sembilan) dalam kekristenan (Kel 20:2-17, kemudian di Ul 5:6-21). Pemaknaan terhadap manusia yang Imago Dei (Kej 1: 27) dijadikan dasar berpikir logis sebab Imago Dei meliputi karakter dan kreativitas logis manusia. Dalam Perjanjian Lama, Imago Dei merupakan proyeksi rupa Tuhan yang mengindikasi manusia memiliki karakter keilahian dalam dirinya. Imago Dei dalam kitab Kejadian diterjemahkan dari kata Ibrani Tselem dan Demuth. Kombinasi dari kata ini diterjemahkan dalam bahasa Yunani menjadi Image yang berarti gambar dalam pemahaman ini menjadikan manusia memiliki keistimewaan diantara kreasi ilahi lainnya. Pandangan teolog neo-orthodoks, Karl Barth menegaskan bahwa kesegambaran meliputi intelektual dan rasio seseorang. Ia menolak kesegambaran rupa Tuhan dengan manusia merujuk pada deskripsi antropomorphis. ${ }^{21}$ Adanya hegemoni institusi agama sebagai sebuah lembaga yang mengikat dan mengonstruksi serta menginformasikan tindakan yang benar dan yang salah (dosa) dalam hal ini dapat menekan penyebaran hoax bagi orang-orang beragama.

\section{Praksis: Pemuka Agama}

Selain itu ditemukan bahwa pemuka agama juga berperan dalam membangun sikap anti hoax dalam masyarakat beragama. Peran tersebut meliputi khotbah edukatif dengan penekanan khusus pada prilaku kritis sebagai makhluk yang imagodei peran persuasif oleh pemuka agama ini berdasarkan hasil penelitian terlihat dengan menuntut untuk menggunakan nalar memengaruhi dan menjadikan orang-orang tidak terlalu tergesa-gesa menghakimi kebenaran suatu informasi sehingga tidak menimbulkan konflik dan menjadi

${ }^{21}$ Lucky Hutasoit, "Memahami Imago Dei Sebagai Potensi Ilahi Dalam Pelayanan," Epigraphe 1, no. 1 (2017): 41. 
penyebar hoax. Edukasi untuk tidak mengadopsi budaya 'salin-teruskan' tanpa lebih dahulu meneliti sebuah informasi atau memproses dengan rasionalitas yang sehat dengan menguji kebenaran sesuai kapasitas masing-masing juga ditekankan. Hal ini untuk menghindari kebenaran yang tidak ideal yang sering dibangun sedemikian apik rupanya sehingga sulit dibedakan. Apa yang dipercayai oleh kebanyakan orang akan menjadi kebenaran. Padahal kebenaran dalam konsep demikian dapat menimbulkan kesesatan.

Dalam teori sosiologis untuk mengidentifikasi proses tindakan 'salin teruskan' ini sebagai sebuah disposisi, atau pemahaman sangatlah kompleks. Pierre Bordieu menyebutkan bahwa persepsi dominan dapat masuk ke dalam persepsi seorang individu tanpa dapat ia sadari sama sekali. Sesungguhnya merunut teori Bordieu seorang sosiologi Prancis mengidentifikasi dan menguraikan pendapat pandangan Marx yang menyebutkan bahwa modal memiliki sifat yang kompleks. Bourdieu melihat modal melingkupi modal simbolik seperti harga diri, martabat, populasi dan atensi. ${ }^{22}$ Seseorang akan berupaya untuk mengupayakan sebanyak mungkin modal-modal simbolik tersebut untuk membangun prestise sosial "kelas atas" sebagai stratifikasi sosial bagi dirinya. Misalnya dalam masyarakat akademik penggunaan Bahasa Inggris dengan aksesn British merupakan sebuah standar dalam mengidentifikasi kemampuan seseorang oleh sebab itu maka setiap orang akan berupaya megucapkan kalimatnya dalam Bahasa Inggris dengan aken Britsh untuk mendapatkan pengakuan publik. Dalam kasus budaya 'salin teruskan' ini timbulnya kesan up to date apabila membagikan berita dengan cepat oleh masyarakat menjadikan persepsi ini terus diupayakan oleh agen-agen sosial untuk mendapatkan modal simbolik tersebut. Sehingga individu mungkin untuk saling berkompetisi menjadi orang yang lebih up to date (terbaru) dalam hal informasi untuk itu agen akan berupaya mengubah tindakan-tindakannya, tindakan copy paste dan membagikan sebuah berita tanpa melalui klarifikasi merupakan jalan pintas.

Sehubnungan dengan hal itu kompetensi dasar serta tekanan khusus oleh pemuka agama diberikan dengan mengajarkan kepribadian iman yang dewasa yang menjunjung tinggi nilai-nilai kemanusiaan dan kehidupan dengan mendayagunakan nalar-dan akal yang sehat. Dengan harapan bahwa perilaku yang terbentuk itu seharusnya terlihat dalam ilmu pengetahuan dan teknologi. Hal ini diharapkan membawa perubahan-perubahan sosial sikap dan pola kehidupan manusia yang berubah. Pemuka agama merasa bertanggungjawab memberikan pengetahuan dan etis yang berhubungan dengan realitas terkini dari berbagai sudut pandang kepada umat beragama melalui khotbah setiap minggu yang kontekstual pada fenomena dan peristiwa terkini sehingga nilai-nilai agama

22 Donny Siburian, "Menggugat Perceraian: Aspek-Aspek Kekerasan Gender Dalam Praktek Perceraian (Paulakhon) Pada Masyarakat Batak," Sosiologi: Jurnal Ilmiah Kajian Ilmu Sosial dan Budaya 23, no. 2 (2021): 211-225. 
menjadi sangat relevan untuk dikembangkan dan diimplementasikan dalam praktik kehidupan manusia disamping hal tersebut juga dapat menekan hoax.

\section{Kesimpulan}

Pranata sosial atau social institution adalah himpunan kesatuan individu yang hidup bersama ditandai dengan keeratan hubungan. Faktor itu meliputi nasib yang sama, ideologi yang sama dan nilai yang sama. Agama Kristen sebagai sebuah pranata memiliki peran yang strategis dalam menekan prilaku penyebaran hoax baik secara sistematis melalui dogma atau doktrin tentang dosa dan kesegambaran manusia dengan Allah (imagodei) dan secara praksis melalui pelayanan khotbah yang disampaikan oleh pemuka agama yang memperhatikan realitas terkini (kontekstual) atas fenomena atau peristiwa yang sedang berlangsung. Terlihat sebagai sebuah sistem pranata kekristenan mengatasi kebutuhan mendesak yang bersifat situasional eksternal. Sistem itu harus beradaptasi dengan lingkungan dan kebutuhan-kebutuhannya untuk menjalankan fungsi sosialnya.

\section{Referensi}

Duska, Ronald, and Mariellen Whelan. "Cognitive-Developmental Approach to Moral Education." dalam The Humanist. November-Desember, 1972.

Herlina, Muria. Sosiologi Kesehatan. Surabaya: Muara Karya, 2017.

Hutasoit, Lucky. "Memahami Imago Dei Sebagai Potensi Ilahi Dalam Pelayanan." Epigraphe 1, no. 1 (2017): 39-54.

Kohlberg, L. "Cognitive-Development Theory and the Practice of Collective Moral Education." dalm Group Care: The Educational Path of Youth Aliyah, editor by M. Collins and M. Gottesman. New York: Gordon and Breach, 1971.

Muller, Max. Introduction to Science of Religion. London: Longman Green and Co, 1982.

Nurman, Silmi Novita. "Penguatan Islam Moderat di Era Post Truth." Jurnal Al Aqidah 11, no. 2 (2019): 179-188.

Putro, Widodo Dwi, and Tristam Pascal Moeliono. "Apakah Ada Kebenaran Hukum di Era Post-Trurth.” In Menemukan Kebenaran Hukum Dalam Era Post-Truth, editor Tristan Pascal Moelino, 1-18. Mataram: Sanabil, 2020.

Samho, Bartolomeus. Agama dan Kesadaran Kontemporer. Yogyakarta: Kanisius, 2019.

Siburian, Donny. "Menggugat Perceraian: Aspek-Aspek Kekerasan Gender Dalam Praktek Perceraian (Paulakhon) Pada Masyarakat Batak." Sosiologi: Jurnal Ilmiah Kajian Ilmu Sosial dan Budaya 23, no. 2 (2021): 211-225.

Stabik, Ahmad. “Teori Kebenaran Perspektif Filsafat Ilmu." Jurnal Fikrah 2, no. 1 (2014): 253-271.

Sugiyono. Metode Penelitian Kuantitatif Kualitatif. Bandung: Alfabeta, 2019.

Suryabrata, Sumadi. Psikologi Kepribadian. Jakarta: Raja Grafindo Persada, 2003.

Syuhada, Kharisma Dhimas. "Etika Media di Era Post-Truth"." Jurnal Komunikasi 
Indonesia 5, no. 1 (2017): 75-79.

Ulya. "Post-Truth, Hoax dan Religiusitas di Media Sosial"." Fikrah 6, no. 2 (2018): 283303.

"Anies-Sandi Menang, Warga Pekanbaru ini Cukur Habis Rambutnya - Cakaplah Berpikir Berbuat Bercakap." diakses 5 November 2021. https://www.cakaplah.com/berita/baca/4066/2017/04/20/aniessandimenang-warga-pekanbaru-ini-cukur-habis-rambutnya.

"Anies: Jika Air Hujan Masuk Ke Tanah, Insyaallah Tak Ada Banjir." diakses 5 November 2021. https://news.detik.com/berita/d-4309249/anies-jika-air-hujan-masuk-ketanah-insyaallah-tak-ada-banjir.

"Bidadari Yang Jatuh Dari Langit Sulawesi Ternyata Boneka Seks." diakses 2 Maret 2021. https://www.suara.com/news/2016/05/02/105540/bidadari-yang-jatuhdi-langit-di-sulawesi-ternyata-boneka-seks.

“Kementerian Komunikasi Dan Informatika." diakses 5 November 2021. https://www.kominfo.go.id/content/detail/29641/hoaks-bambang-trihatmodjobuktikan-jokowi-berasal-dari-keluarga-pki/0/laporan_isu_hoaks.

"Klaim Bisa Sembuhkan Penderita Virus Corona, Pendeta Ini Meninggal Karena Penyakit Yang Sama Halaman All - Kompas.Com." Accessed March 20, 1BC. https://www.kompas.com/global/read/2020/05/20/134441970/klaim-bisasembuhkan-penderita-virus-corona-pendeta-ini-meninggal-karena?page=all.

"Kolom: Pandemi Corona Pertanda Akhir Zaman? | SOSBUD: Laporan Seputar Seni, Gaya Hidup Dan Sosial | DW | 12.03.2020." diakses 2 Maret 2021. https://www.dw.com/id/kolom-pandemi-corona-pertanda-akhir-zaman/a52739489.

“Sejarah Kerajaan Sunda Empire Di Bandung Jawa Barat | Tagar." diakses 5 November 2021. https://www.tagar.id/sejarah-kerajaan-sunda-empire-di-bandung-jawabarat.

"Teka-Teki Bocah Bertelur Itu Akhirnya Terbongkar, Polisi Pun Menutup Kasusnya." diakses 2 Maret 2021. https://www.tribunnews.com/regional/2018/03/05/teta-teki-bocah-berteluritu-akhirnya-terbongkar-polisi-pun-menutup-kasusnya. 